\title{
Article
}

\section{Efektivitas Fungsi Pendamping Lokal Desa Dalam Pembangunan Desa Tunggul Bulin Kecamatan Tabir Ilir Kabupaten Merangin}

\author{
Harpin Syah ${ }^{*}$, Asmu ${ }^{2}$
}

This article is an open access article distributed under the terms and conditions of the Creative Commons Attribution-ShareAlike 4.0 International (CC BY SA ) License (https://creativecommo ns.org/licenses/by-

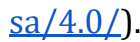

\section{Jurnal Politik dan} Pemerintahan Daerah ISSN 2686-2271

Fakultas Ilmu Sosial dan Ilmu Politik, Universitas Muara Bungo Jl. Diponegoro No. 27, Muara Bungo-Jambi, (0747) 323310

\author{
${ }^{1}$ Program Studi Ilmu Pemerintahan Fakultas Ilmu Sosial Dan Ilmu Politik, Universitas \\ Muara Bungo. Kabupaten Bungo, Provinsi Jambi \\ 2 Program Studi Ilmu Pemerintahan Fakultas Ilmu Sosial Dan Ilmu Politik, Universitas \\ Muara Bungo. Kabupaten Bungo, Provinsi Jambi \\ *Correspondence Author: harpinsyah7@gmail.com
}

Abstract: The purpose of this study was to determine the effectiveness of the function of local village facilitators in village development in Tunggul Bulin Village, Tabir Ilir District, Merangin Regency, and to find out the obstacles to local village assistants in carrying out assistance in village development in Tunggul Bulin Village, Tabir Ilir District, Merangin Regency. The method used in this study is a qualitative research method with a descriptive study. The method used in this study is a qualitative research method with a descriptive study. The informant selection technique used by the researcher in this research is to use the purposive sampling method (the technique of determining the sample with certain considerations). The results of this study indicate that the function of village assistants has been effective in village development in Tunggul Bulin Village, Tabir Ilir District, Merangin Regency, the functions that have been carried out include planning development in the village and preparing village development plans through village deliberations. have not been able to carry out the mandate of the Law, especially on assistance carried out by local village assistants (PLD), several obstacles PLD in carrying out the function of assisting the development of Tunggul Bulin Village, Tabir Ilir District, Merangin Regency, including: low community participation and low technical capacity of village officials, Efforts to What the local village assistants do in overcoming development problems include increasing community participation in development and increasing the capacity of village officials, as well as compiling a schedule of activities.

Keywords: Effectiveness, Village Local Facilitator, Village Development

Abstrak: Tujuan dilakukan penelitian ini adalah untuk mengetahui efektivitas fungsi pendamping lokal desa dalam pembangunan desa di Desa Tunggul Bulin Kecamatan Tabir Ilir Kabupaten Merangin, serta mengetahui hambatan pendamping lokal desa dalam melaksanakan pendampingan dalam pembangunan desa di Desa Tunggul Bulin Kecamatan Tabir Ilir Kabupaten Merangin. Metode yang digunakan dalam penelitian ini penelitian ini adalah metode penelitian kualitatif yang bersifat dengan studi deskriptif. Metode yang digunakan dalam penelitian ini penelitian ini adalah metode penelitian kualitatif yang bersifat dengan studi deskriptif. Teknik pemilihan informan yang digunakan oleh peneliti dalam penelitian ini adalah dengan menggunakan metode purposive sampling (teknik penentuan sampel dengan pertimbangan tertentu). Hasil penelitian ini menunjukkan bahwa fungsi pendamping desa telah efektif dalam pembangunan desa di Desa Tunggul Bulin Kecamatan Tabir Ilir Kabupaten Merangin, fungsi yang telah dijalankan diantaranya adalah melalui perencanaan pembangunan di desa dan penyusunan rencana pembangunan desa melalui musyawarah desa, Terkait dengan kegiatan pembangunan desa, masih belum dapat melaksanakan amanat UU 
tersebut terutama terhadap pendampingan yang dilakukan oleh pendamping lokal desa (PLD), beberapa hambatan PLD dalam menjalankan fungsi pendampingan pembangunan Desa Tunggul Bulin Kecamatan Tabir Ilir Kabupaten Merangin, diantaranya adalah: rendahnya partisipasi masyarakat dan rendahnya kemampuan teknis perangkat desa, Upaya yang dilakukan pendamping lokal desa dalam mengatasi masalah pembangunan diantaranya adalah meningkatkan partisipasi masyarakat dalam pembangunan dan meningkatkan kemampuan perangkat desa, serta menyusun jadwal kegiatan.

Kata Kunci: Efektivitas, Pendamping Lokal Desa, Pembangunan Desa

\section{Pendahuluan}

Kehadiran Undang-undang Nomor 6 tahun 2014 tentang Desa menendai babak baru dan perubahan dalam politik pembangunan nasional, dimana desa menjadi titik tumpuh yang mendapatkan perhatian serius. Selain itu juga memberikan harapan sekaligus tantangan baru bagi Desa. Dalam undang-undang tersebut pemberdayaan menjadi sebuah misi, tujuan, asas dan agenda kebijakan yang secara prinsip diwujudkan dengan mengakui dan menetapkan kewenangan desa, sementara pemerintah berkewajiban menjamin agar desa mampu melaksanakan upaya pemberdayaan, pembinaan dan pengawasan.

Seperti yang tertuang dalam Pasal 112 Ayat 1 Undang-undang Nomor 6 tahun 2014 tentang Desa, pemerintah, pemerintahan daerah provinsi, dan pemerintah daerah kabupaten atau kota bertugas untuk membina dan mengawasi penyelenggaraan pemerintahan desa. Yang artinya desa haruslah mendapatkan bimbingan, pembinaan, serta pengawasan didalam menyelenggarakan pemerintahan, pembangunan dan pelayanannya terhadap masyarakat sekaligus memberdayakan masyarakat itu sendiri. (Undang-Undang, 2014)

Pembangunan Desa dilaksanakan dengan konsep Pemberdayaan Masyarakat Desa dengan tujuan mengembangkan kemandirian dan kesejahteraan masyarakat dengan meningkatkan pengetahuan, sikap, keterampilan, perilaku, kemampuan, kesadaran, serta memanfaatkan sumber daya melalui penetapan kebijakan, program, kegiatan, dan pendampingan yang sesuai dengan esensi masalah dan prioritas kebutuhan masyarakat Desa. Pemberdayaan masyarakat Desa dilaksanakan dengan pendampingan dalam perencanaan, pelaksanaan, dan pemantauan pembangunan Desa dan kawasan Perdesaan. (Pemerintah Republik Indonesia, 2014)

Pendampingan Desa adalah kegiatan untuk melakukan tindakan pemberdayaan masyarakat melalui asistensi, pengorganisasian, pengarahan dan fasilitasi Desa. (Pemerintah Republik Indonesia, 2015) Dalam upaya peningkatan kualitas hidup dan kehidupan untuk sebesar-besarnya kesejahteraan masyarakat desa. (Republik Indonesia, 2014)

Pendamping desa juga memegang peran penting dalam mendorong pendayagunaan lembaga kemasyarakatan Desa dan lembaga adat. Pendamping desa memiliki peran sebagai agen perubahan (agent of change) yang juga berperan sebagai fasilitator, mediator, dan pelaku dalam meningkatkan kesejahterahan ekonomi bagi masyarakat. (Suswanto et al., 2019) Bukan tugas yang mudah, karena selama ini dibanyak tempat, lembaga kemasyarakatan seakan hanya lembaga papan nama saja. Kondisi ini terjadi karena memang lembaga kemasyarakatan di desa tidak pernah mendapat sentuhan. Di Program Nasional Pemberdayaan Masyarakat Perdesaan, Lembaga Pemberdayaan Masyarakat, salah satu lembaga kemasyarakatan ini baru disentuh setelah konsep integrasi digaungkan pada awal 2011. 
Tidak kalah penting, pendamping desa juga dituntut mendorong partisipasi masyarakat dalam penyusunan kebijakan Desa yang dilakukan melalui musyawarah Desa. Kebijakan-kebijakan strategis yang berkaitan dengan desa, utamanya pengelolaan pembangunan desa, harus dipertanggungjawabkan melalui musyawarah desa.

Selanjutnya, Pendamping desa juga memiliki peran penting dalam penguatan organisasi-organisasi desa. (Susanti, 2017) Pendamping desa juga bertugas mendorong pengawasan dan pemantauan penyelenggaraan Pemerintahan desa dan pembangunan Desa yang dilakukan secara partisipatif oleh masyarakat Desa. Pengawasan secara kelembagaan menjadi tugas utama Badan Permusyawaratan Desa dan secara partisipatif menjadi hak dan kewajiban masyarakat desa. Karena itu mendorong penguatan fungsi Badan Permusyawaratan Desa sehingga otonomi desa merupakan otonomi yang asli, bulat dan utuh. (Widjaja, 2012)

Tahap selanjutnya, pendamping desa bahkan dituntut untuk melakukan penyadaran kepada masyarakat desa akan hak dan kewajibannya sebagai warga desa. Pada tahap ini, pendamping desa harus memerankan diri sebagai community organizer yang harus jeli membaca fenomena hubungan sosial antar kelembagaan dan masyarakat.

Dengan demikian pendamping desa yang dimaksud dapat berhubungan langsung secara intensif dengan pemerintah dan masyarakat desa, menjadi actor yang strategis menuju implementasi UU Desa secara optimal. Pendamping desa adalah kegiatan untuk melakukan tindakan pemberdayaan masyarakat melalui asistensi, pengorganisasian, pengarahan dan fasilitasi desa. Misi besar pendamping desa adalah pemberdayaan masyarakat desa menjadi maju, kuat, mandiri dan demokratis. Kegiatan pendampingan membentang dari pembangunan kapasitas pemerintah, mengorganisasi dan membangun kesadaran kritis masyarakat. Selain itu juga memfasilitasi pembangunan partisipatif, memfasilitasi dan memperkuat musyawarah desa sebagai arena demokrasi dan akuntabilitas lokal hingga mengisi kekosongan antara pemerintah dan masyarakat. Intinya pendampingan desa adalah menciptakan suatu frekuensi yang sama antara pendamping dengan yang didampingi. UU Nomor 6 Tahun 2104 mengembangkan paradigma dan konsep baru kebijakan tata kelolah desa secara nasional termasuk mengenai fungsi dan peran pendampingan desa.

Dalam mendamping desa dan melakukan pemberdayaan masyarakat haruslah didampinging oleh pendamping desa yang dimana tenaga pendamping desa yang bertugas di kecamatan untuk mendampingi desa dan mampu mendampingi pendamping lokal desa (PLD).

Berdasarkan observasi awal peneliti di DesaTunggul Bulin Kecamatan Tabir Ilir diketahui bahwa salah satu keluhan tentang petugas Pendamping Desa sebagaimana disuarakan oleh Bapak Laduni selaku Kepala DesaTunggul Bulin. Menurut beliau keberadaan petugas kurang maksimal dalam menjalankan perannya, karena fokus pekerjaan tidak hanya menyasar ke satu desa dikarenakan keterbatasan jumlah pendamping desa yang idealnya satu desa satu pendamping. Sementara untuk wilayah Tabir Ilir sendiri hanya ada dua pendamping desa yang bertugas mendampingi 7 (tujuh) desa, artinya satu pendamping desa diharuskan mampu mendampingi sebanyak 3 hingga 4 desa. Akibatnya, pihak desa merasa bekerja sendirian untuk mewujudkan penyerapan dana desa semaksimal mungkin (Wawancara, 7 Desember 2017).

Beliau juga mengatakan, bahwa kondisi georafis desa yang berjauhan menjadi kendala dalam pendampingan yang dilakukan oleh pendamping desa, sehingga jarak tempuh yang cukup jauh tersebut membuat pendampingan kurang maksimal, baik dari segi ketepatan waktu maupun kondisi fisik pendamping yang lelah 
mengakibatkan pendampingan yang diberikan sekedarnya saja, sekedar memenuhi kewajiban.

Pernyataan yang sama juga disampaikan oleh Bapak Ahmad Kholidi selaku pendamping desa Tunggul Bulin, menurut beliau kendala yang dihadapi dalam pendampingan desa adalah minimnya petugas pendamping desa yang ditempatkan di desa, sehingga pelaksanaan pendampingan kurang maksimal. Karena sepengetahuan beliau bahwa pendampingan desa bukanlah mendampingi pelaksanaan proyek yang masuk ke desa, bukan pula mendampingi dan mengawasi penggunaan Dana Desa, tetapi melakukan pendampingan secara utuh terhadap desa. Pendampingan secara prinsipil berbeda dengan pembinaan. Dalam pembinaan, antara pembina dan yang dibina, mempunyai hubungan yang hirarkhis, sehingga pengetahuan dan kebenaran mengalir satu arah dari atas ke bawah. Sebaliknya dalam pendampingan, para pendamping berdiri setara dengan yang didampingi (stand side by side).

Berdasarkan uraian diatas maka penulis tertarik untuk meneliti lebih lanjut mengenai Efektivitas Fungsi Pendamping Lokal Desa Dalam Pembangunan Desa Tunggul Bulin Kecamatan Tabir Ilir Kabupaten Merangin

\section{Pembahasan}

\section{Efektivitas Fungsi Pendamping Lokal Desa Dalam Pembangunan Desa di Desa Tunggul Bulin Kecamatan Tabir Ilir Kabupaten Merangin}

Undang-undang Nomor 6 Tahun 2014 tentang Desa telah jelas menegaskan bawha pemberdayaan masyarakat desa sebagaimana dilaksanakan dengan pendampingan dalam perencanaan, pelaksanaan, dan pemantauan pembangunan desa dan kawasan perdesaan. Sehingga pemerintah berkewajiban untuk memberikan pendampingan kepada desa dalam rangka pemberdayaan masyarakat desa, besarnya alokasi dana desa yang akan mengalir ke desa, melalui pendamping proses musyawarah desa membentuk RPJM (rencana pembangunan jangka menengah desa)/RKP (rencana kerja pemerintah desa), maka anggaran tersebut dapat dipergunakan secara tepat sasaran sesuai kebutuhan pembangunan desa.

Pemberdayaan dilakukan dengan pendampingan dalam perencanaan, pelaksanaan dan pemantauan pembangunan desa dan kawasan perdesaan. Pendampingan Masyarakat Desa sebagaimana dalam PP No 43 tahun 2014 diperjelas dan pertegas pada pasal 129 yaitu sebagai berikut : Tenaga pendamping professional yang terdiri atas:

a. pendamping Desa yang bertugas mendampingi Desa dalam penyelenggaraan Pemerintahan Desa, kerja sama Desa, pengembangan BUM Desa, dan pembangunan yang berskala lokal Desa;

b. pendamping teknis yang bertugas mendampingi Desa dalam pelaksanaan program dan kegiatan sektoral; dan

c. tenaga ahli pemberdayaan masyarakat yang bertugas meningkatkan kapasitas tenaga pendamping dalam rangka penyelenggaraan Pemerintahan Desa, pelaksanaan pembangunan Desa, pembinaan kemasyarakatan Desa, dan pemberdayaan masyarakat Desa.

Sering kali terdengar sebuah pertanyaan "apa peran pendamping desa?" dengan nada sinis dan penuh kecurigaan. Seolah tanpa adanya pendampingan, maka pembangunan dan pemberdayaan akan tetap berjalan dengan sendirinya, bukankah sudah ada aturan yang harus di ikuti dan banyaknya mata yang mengawasi ke desa akhir-akhir ini, sehingga seharusnya tidak ada masalah dan kegiatan di desa tetap berjalan seperti biasanya. 
Jika kita melihat dari dua hal, yang pertama, soal akhir kegiatan yang dapat dilaksanakan oleh desa, dan kedua, soal anggaran yang harus dikeluarkan untuk menggaji pendamping yang dapat di hemat, semua kesimpulan yang diambil diatas mungkin terasa benar. Namun jika kita bicara soal kualitas dari dana desa atau alokasi dana desa tanpa pendampingan, sudahkah inklusifitas tercipta di dalam APBDesa? Dimana setiap sudut desa merasakan manfaat dari dana desa tersebut, baik sebagai pelaku ataupun objek pembangunan.

Kemudian, cukup dengan aturan maka desa sudah tertib, apakah artinya kita sudah menghargai hak-hak desa yang ada didalam UU No 6 tahun 2014 tentang desa dengan beragam turunannya? Dimana setiap tahun, prioritas dana desa haruslah dibuat peraturannya yang disesuaikan dengan pencapaian yang dilakukan tahun sebelumnya, misalnya, jika jalan desa sepanjang 1 juta kilometer telah terbangun, darimanakah dana perbaikannya dimasa depan seandainya UU desa dicabut atau direvisi sesuai kondisi negara dimasa depan.

Melakukan pemberdayaan di dalam lingkup desa, berarti ada penyamaan persepsi pembangunan yang sama di antara 74.754 desa se Indonesia dengan dinamika masyarakat yang bisa saja berbeda antara satu kabupaten dengan kabupaten lainnya, bahkan dalam lingkup antar dusunpun dapat berbeda persepsi, mungkin disatu desa, posisi matrilinier masih kental terasa, atau suara ninik mamak yang harus didengarkan daripada suara seorang camat sekalipun, ditempat lain mungkin kita dapat berbicara lugas tanpa batasan, di sisi lain, tutur kata haruslah dijaga untuk menghormati tuan rumah.

Menyamakan seluruh desa, bahwa dana desa untuk menciptakan inklusifitas tanpa memandang perbedaan kelamin, ras, suku bangsa itu secara teori mungkin terasa mudah, namun sayangnya, watak manusia tidak hanya tergambar dengan mudah oleh zodiak atau shio yang bisa diramal setiap saat.

Mensosialisasikan tentang UU No 6 tahun 2014 kepada masyarakat desa bukanlah hal yang mudah, karena dalam proses sosialiasi ini, kita ikut serta membangunkan kesadaran masyarakat desa untuk membangun desanya sendiri.

Efektivitas fungsi pendamping lokal desa dalam pembangunan desa di Desa Tunggul Bulin Kecamatan Tabir Ilir Kabupaten Merangin dilihat berdasarkan teori Sondang P. Siagian, dimana efektivitas kerja organisasi sangat tergantung dari efektivitas kerja dari orang-orang yang bekerja didalamnya. Ada beberapa kriteria yang dapat digunakan untuk mengukur efektivitas kerja dari organisasi dalam memberikan pelayanan antara lain :

\section{Faktor waktu}

Faktor waktu di sini maksudnya adalah ketepatan waktu dan kecepatan waktu dari pelayanan yang diberikan oleh pemberi pelayanan. Hanya saja penggunaan ukuran tentang tepat tidaknya atau cepat tidaknya pelayanan yang diberikan berbeda dari satu orang ke orang lain. Terlepas dari penilaian subjektif yang demikian, yang jelas ialah faktor waktu dapat dijadikan sebagai salah satu ukuran efektivitas kerja.

Berdasarkan hasil wawancara dengan beberapa informan diketahui bahwa faktor waktu pendampingan yang diberikan pendamping desa dalam pembangunan desa di Desa Tunggul Bulin Kecamatan Tabir Ilir Kabupaten Merangin sudah efektif hanya saja belum maksimal. Pemerintah Desa menyusun perencanaan Pembangunan Desa sesuai dengan kewenangannya dengan mengacu pada perencanaan pembangunan Kabupaten/Kota. Perencanaan dan Pembangunan Desa dilaksanakan oleh Pemerintah Desa dengan melibatkan seluruh masyarakat Desa dengan semangat gotong royong. Masyarakat Desa berhak melakukan pemantauan terhadap pelaksanaan Pembangunan Desa. 
Dalam rangka perencanaan dan pelaksanaan pembangunan Desa, pemerintah Desa didampingi oleh pemerintah daerah kabupaten/kota yang secara teknis dilaksanakan oleh satuan kerja perangkat daerah kabupaten/kota. Untuk mengoordinasikan pembangunan Desa, kepala desa dapat didampingi oleh tenaga pendamping profesional, kader pemberdayaan masyarakat Desa, dan/atau pihak ketiga.

Seperti di desa-desa yang lain, diakhir tahun setiap desa di Kecamatan Tabir Ilir juga mengadakan kegiatan Musrenbangdes atau musyawarah rencana pembangunan desa untuk setahun yang akan datang (2019). Pemerintah Desa Tunggul Bulin menggelar Musyawarah Rencana Pembangunan Desa (Musrenbangdes). Musyawarah yang dilaksanakan di Aula Balai Desa Tunggul Bulin pada tanggal 29 Januari 2018, dihadiri oleh Kepala Desa beserta Perangkat Desa, Kasi PMD Kecamatan Tabir Ilir, BPD, LPMD, Kepala Dusun, KPMD, Kader PKK, PLD, serta perwakilan Tokoh Masyarakat dan Tokoh Agama.

2. Faktor kecermatan

Faktor kecermatan dapat dijadikan ukuran untuk menilai tingkat efektivitas kerja organisasi yang memberikan pelayanan. Faktor kecermatan disini adalah faktor ketelitian dari pemberi pelayanan kepada pelanggan. Pelanggan akan cenderung memberikan nilai yang tidak terlalu tinggi kepada pemberi pelayan, apabila terjadi banyak kesalahan dalam proses pelayanan, meskipun diberikan dalam waktu yang singkat.

Berdasarkan hasil wawancara dengan beberapa informan diketahui bahwa kecermatan pendampingan yang diberikan pendamping desa dalam pembangunan desa di Desa Tunggul Bulin Kecamatan Tabir Ilir Kabupaten Merangin sudah efektif hanya saja belum maksimal, hal ini terlihat dari beberapa permasalahan dalam proses perencanaan pembangunan.

Titik berat dalam permasalahan mayoritas desa bukanlah kurangnya minat partisipasi masyarakat untuk turut andil dalam perencanaan pembangunan desa melalui musyawarah, setelah ditelusuri ternyata dikarenakan mayoritas sumber daya pemerintah desa belum cukup cakap dalam pembuatan dokumen perencanaan desa baik RKPDesa maupun RPJMDesa yang sesuai dengan sistematika dan tahapan penyusunannya. Pemerintah desa mengaku bingung sekalipun sudah mendapatkan pelatihanpelatihan dari SKPD terkait. Fungsi pengawasan dari BPD pun kurang berjalan sehingga adanya pembiaran yang bersifat kritis dalam kinerja pemerintah desa. Kualitas sumber daya manusia perangkat desa belum mampu melaksanakan tugas administrasi yang begitu rumit, hal ini membuktikan bahwa perlunya pendampingan oleh pendamping desa, dengan adanya pendamping diharapkan terjadi peningkatan kualitas SDM perangkat desa sehingga mampu mandiri dalam pembuatan dokumen perencanaan.

Di lain hal, ternyata mayoritas desa-desa binaan menggunakan jasa konsultan dalam pembuatan dokumen desa, dan penganggarannya sudah ada dalam APBDesa. Jadi prakteknya, desa melakukan musyawarah, menggali usulan desa, kemudian tim penyusun mengonsultasikan kembali kepada pemberi jasa.

3. Faktor gaya pemberian pelayanan

Gaya pemberian pelayanan merupakan salah satu ukuran lain yang dapat dan biasanya digunakan dalam mengukur efektivitas kerja. Yang dimaksud dengan gaya disini adalah cara dan kebiasaan pemberi pelayanan dalam memberikan jasa kepada pelanggan. Bisa saja si pelanggan merasa tidak sesuai dengan gaya pelanggan yang diberikan oleh pemberi pelayanan. 
Jika berbicara tentang sesuatu hal yang menyangkut kesesuaian, sesungguhnya apa yang dibicarakan termasuk hal yang tidak terlepas kaitannya dengan nilai-nilai sosial yang dianut oleh orang yang bersangkutan.

Berdasarkan hasil wawancara dengan beberapa informan diketahui bahwa gaya pemberian pelayanan pendampingan yang diberikan pendamping desa dalam pembangunan desa di Desa Tunggul Bulin Kecamatan Tabir Ilir Kabupaten Merangin sudah efektif, hal ini terlihat dari kemampuan pendamping desa dalam mengatasi permasalahan dalam proses perencanaan pembangunan.

Mayoritas desa-desa binaan menggunakan jasa konsultan dalam pembuatan dokumen desa, dan penganggarannya sudah ada dalam APBDesa. Jadi prakteknya, desa melakukan musyawarah, menggali usulan desa, kemudian tim penyusun mengonsultasikan kembali kepada pemberi jasa

Maka, untuk mengatasi hal ini, sesuai dengan rencana tindak lanjut tenaga pendamping untuk merealiasikan praktek UU Desa, tenaga pendamping desa melakukan inovasi secara bertahap dengan harapan utama: agar desa terbiasa menyelesaikan kebutuhan di desa secara mandiri. Tentu saja jika dianalogikan seperti seorang anak tumbuh dewasa dan makin dewasa melewati masa waktu dan pembelajaran untuk bisa mandiri, perlu usaha keras dari dirinya sendiri dan didukung oleh lingkungan sekitar untuk bisa mandiri. Keberadaan pendamping lokal desa sangat efektif dalam membina pemerintahan desa dalam mengupayakan perangkat desa yang berkualitas, karena efektivitas merupakan salah satu dimensi dari produktivitas, yaitu mengarah kepada pencapaian unjuk kerja yang maksimal, yaitu pencapaian target yang berkaitan dengan kualitas, kuantitas dan waktu.

\section{Hambatan Pendamping Desa dalam melaksanakan pendampingan dalam pembangunan desa di Desa Tunggul Bulin Kecamatan Tabir Ilir Kabupaten Merangin}

Undang-Undang No 6 Tahun 2014 selain memberi kewenangan yang lebih luas kepada pemerintahan desa untuk melaksanakan tugas pembangunan desa yang dibuktikan dengan kebijakan pengalokasian anggaran APBN untuk desa yang dari tahun ke tahun jumlahnya semakin meningkat, juga mengamanatkan bahwa perencanaan pembangunan desa harus dilaksanakan secara partisipatif, melibatkan seluruh masyarakat termasuk kelompok rentan (minoritas, difabel, perempuan, miskin).

Hal itu bertujuan agar pembangunan yang dilaksanakan oleh desa benar-benar bermanfaat bagi seluruh warga masyarakat di desa, termasuk warga masyarakat yang tergolong sebagai kelompok rentan.

Berdasarkan hasil wawancara dan observasi di Desa Desa Tunggul Bulin Kecamatan Tabir Ilir diketahui bahwa terkait dengan kegiatan pembangunan desa, masih belum dapat melaksanakan amanat UU tersebut terutama terhadap pendampingan yang dilakukan oleh pendamping lokal desa (PLD), beberapa hambatan Pendamping Lokal Desa (PLD) dalam menjalankan fungsi pendampingan pembangunan Desa Tunggul Bulin Kecamatan Tabir Ilir Kabupaten Merangin, diantaranya adalah:

1. Rendahnya Partisipasi Masyarakat

Memang selama ini Desa Tunggul Bulin sudah bisa melaksanakan perencanaan pembangunan, namun umumnya masih belum secara partisipatif. Selama ini Desa Tunggul Bulin melaksanakan perencanaan pembangunan secara elitis yaitu sepenuhnya dilakukan oleh pemerintahan desa, baik dilaksanakan sendiri oleh kepala desa, aparat desa, dan BPD, maupun dilakukan oleh orang yang menjadi konsultan dalam perencanaan pembangunan desa. 
Namun sejak bebarapa tahun terakhir sudah melibatkan masyarakat dalam melaksanakan perencanaan pembangunan yaitu melalui mekanisme musrenbangdes, walaupun belum maksimal.

Konsep pembangunan desa telah menempatkan perlakuan terhadap masyarakat dalam pembangunan pada posisi yang begitu berarti dan sentral. Sehingga keterlibatannya dalam proses pembangunan menjadi titik penentu apakah proses pembangunan itu menjadi wahana proses belajar atau hanya sekedar sebuah rekayasa yang mana pemerintah menjadi pemain tunggal. Dengan demikian penekanan pada aspek "proses" memiliki arti penting. Proses belajar mengandung makna bahwa setiap kekurangan dan kelemahan yang muncul dalam proses pelaksanaan program pembangunan menjadi informasi yang penting dan untuk itu dilakukan upaya-upaya penanggulangannya.

Pembangunan melalui partisipasi masyarakat merupakan salah satu upaya untuk memberdayakan potensi masyarakat dalam merencanakan pembangunan yang berkaitan dengan potensi sumber daya lokal berdasarkan kajian musyawarah, yaitu peningkatan aspirasi berupa keinginan dan kebutuhan nyata yang ada dalam masyarakat melalui usulan, saran dan kritik serta kehadiran masyarakat dalam musyawarah. Peningkatan keaktifan dan peran serta kelompok masyarakat dalam proses pembangunan, dan peningkatan rasa memiliki pada kelompok masyarakat terhadap program kegiatan yang telah disusun. Partisipasi masyarakat dalam tahap penyusunan rencana dengan memberikan usulan-usulan mengenai program, keaktifan memberikan saran dan kritik serta tingkat kehadiran masyarakat dalam pertemuan terkait dengan musyawarah rencana pembangunan di Desa Tunggul Bulin.

Tidak semua unsur masyarakat diundang, jikapun datang banyak yang tidak memberikan aspirasi karena takut bicara atau minder, sehingga dampak yang terjadi akibat perencanaan pembangunan yang belum partisipatif adalah pelaksanaan pembangunan desa yang selama ini dilaksanakan oleh sebagian besar desa-desa di Indonesia belum bisa dirasakan manfaatnya oleh seluruh lapisan masyarakat. Padahal pelaksanaan pembangunan desa belum bisa dikatakan berhasil bila masih ada sebagian warga masyarakat yang belum bisa merasakan manfaat dari pelaksanaan pembangunan tersebut.

Pelaksanaan pembangunan di desa bisa dirasakan manfaatnya oleh seluruh warga masyarakat di desa, dan tidak ada satupun warga masyarakat yang merasa terabaikan, sehingga cita-cita luhur para pendiri bangsa ini, yaitu terciptanya masyarakat yang sejahtera, adil makmur dan merata dapat segera diwujudkan.

\section{Rendahnya Kemampuan Teknis Perangkat Desa}

Permasalahan lain yang menjadi hambatan Pendamping Lokal Desa (PLD) dalam menjalankan fungsi pendampingan pada proses penyusunan dokumen perencanaan pembangunan Desa Tunggul Bulin adalah kurangnya kemampuan teknis perencanaan pembangunan desa, tercermin dari dokumendokumen perencanaan desa yang belum lengkap.

Selain itu pelaksanaan Musrenbang Desa di Desa Tunggul Bulin tidak berlangsung secara optimal. Adanya keterbatasan anggaran juga berpengaruh besar pada penyusunan anggaran pendapatan dan belanja desa (APBDes). Adanya loncatan-loncatan dalam penyusunan dokumen perencanaan pembangunan tersebut memperlihatkan, bahwa pada dasarnya pemahaman teknis perencanaan pembangunan desa yang dimiliki perangkat desa Desa Tunggul Bulin belum memadai karena perangkat desa belum dibekali dengan diklat/bintek yang diperlukan, sehingga perangkat desa hanya melakukan 
kegiatan-kegiatan secara rutin seperti tahun-tahun sebelumnya, padahal kebijakan mekanisme perencanaan pembangunan desa sudah mengalami perubahan yang sangat mendasar.

3. Luasnya Wilayah Pendampingan/Binaan

Permasalahan lain yang menjadi hambatan Pendamping Lokal Desa (PLD) dalam menjalankan fungsi pendampingan adalah luasnya wilayah pendampingan, dikarenakan jarak satu desa dengan desa lainnya yang cukup jauh.

Kondisi tersebut menggambarkan bahwa struktur wilayah yang luas menjadi kendala bagi pendamping lokal desa dalam pendampingan, selain itu adat kebiasaan masyarakat yang kumpul di malam hari juga menjadi penghambat. Sehingga mengakibatkan pendampingan Desa dalam perencanaan, pelaksanaan, dan pemantauan terhadap pembangunan Desa dan pemberdayaan masyarakat Desa tidak dapat berjalan dengan maksimal.

4. Minimnya honor Pendamping Lokal Desa

Permasalahan lain yang menjadi hambatan Pendamping Lokal Desa (PLD) dalam menjalankan fungsi pendampingan pada proses penyusunan dokumen perencanaan pembangunan Desa Tunggul Bulin adalah minimnya honor yang diterima pendamping lokal desa.

\section{Upaya Pendamping Lokal Desa dalam Mengatasi Masalah Pembangunan}

Berdasarkan wawancara dengan pendamping lokal Desa Tunggul Bulin Kecamatan Tabir Ilir Kabupaten Merangin upaya yang dilakukan Pendamping Lokal Desa dalam mengatasi masalah pembangunan diantarnya adalah:

1. Meningkatkan Partisipasi Masyarakat dalam Pembangunan

Menurut Pendamping Lokal Desa Tunggul Bulin, pemerintah desa tidak boleh ketergantungan dengan Pendamping Lokal Desa, pemerintah desa harus mengupayakan meningkatkan partisipasi masyarakat dalam pembangunan, karena keterlibatan masyarakat secara aktif akan membantu pemerintah desa dalam merencanakan, melaksanakan, dan mengawasi pembangunan itu sendiri.

2. Meningkatkan Kemampuan Perangkat Desa

Upaya lain yang dilakukan pemerintah desa dalam mengatasi masalah kurangnya jumlah pendamping desa adalah dengan meningkatkan kemampuan perangkat desa. Efektivitas pembangunan pada hakikatnya merupakan tindakan membandingkan antara perencanaan dengan hasil. Antara kedua hal tersebut sering terjadi penyimpangan. Tugas PLD adalah mengoreksi penyimpangan tersebut. Pembangunan desa adalah strategi pembangunan bagi peningkatan kehidupan ekonomi dan sosial dari kelompok khusus masyarakat, dalam hal ini masyarakat kurang mampu di pedesaan. Pembangunan desa bertujuan mengurangi kemiskinan serta tersedianya sarana dan prasarana umum untuk menunjang segala kebutuhan masyarakat yang ternyata masih kurang untuk membantu masyarakat desa dalam beraktivitas sehari-hari.

ADD adalah dana yang dialokasikan pemerintah kabupaten/kota untuk desa yang bersumber dari bagian dana perimbangan keuangan pusat dan daerah yang diterima kabupaten/kota. Anggaran Pendapatan dan Belanja Desa (APB Desa) adalah rencana keuangan tahunan pemerintahan desa yang dibahas dan disetujui bersama oleh pemerintah desa dan Badan Permusyawaratan Desa (BPD) yang ditetapkan dengan peraturan desa. ADD merupakan dukungan dana dari pemerintah pusat dan daerah kepada pemerintah desa dalam meningkatkan pelayanan dasar kepada masyarakat dan pemberdayaan masyarakat desa. 
Pengalokasian dana desa butuh fungsi PLD sebagai pengawas agar dana tersebut benar-benar tersalurkan untuk kepentingan pembangunan desa. Pengawasan oleh PLD terhadap anggaran desa dilakukan dengan melihat rencana awal program dan realisasinya. Kesesuaian antara rencana program, realisasi program, pelaksanaan, serta nilai dana yang digunakan dalam pembiayaan adalah ukuran yang dijadikan patokan PLD dalam pengawasan.

\section{Pengaturan Jadwal Pertemuan}

Upaya yang dilakukan Pendamping Lokal Desa (PLD) dalam dalam mengatasi masalah pembangunan karena luasnya wilayah pendampingan, dikarenakan jarak satu desa dengan desa lainnya yang cukup jauh, adalah dengan mengatur jadwal ulang pertemuan.

\section{Penutup}

Fungsi pendamping telah efektif dalam pembangunan desa di Desa Tunggul Bulin Kecamatan Tabir Ilir Kabupaten Merangin. Ada beberapa kriteria yang dapat digunakan untuk mengukur efektivitas kerja dari organisasi dalam memberikan pelayanan antara lain: a) Faktor waktu b) Faktor kecermatan c) Faktor gaya d) Pemberian pelayanan. Selain itu ada beberapa hal yang harus diperhatikan, diantaranya: 1) Beberapa hambatan Pendamping Lokal Desa (PLD) dalam menjalankan fungsi pendampingan pembangunan Desa Tunggul Bulin Kecamatan Tabir Ilir Kabupaten Merangin, diantaranya adalah rendahnya partisipasi masyarakat, Rendahnya kemampuan teknis perangkat desa, Luasnya wilayah pendampingan/binaan, 2) Upaya yang dilakukan untuk mengatasi hal tersebut adalah meningkatkan partisipasi masyarakat, meningkatkan kemampuan perangkat desa, pengaturan jadwal pertemuan.

Saran berikutnya tentang pendamping desa untuk mewujudkan kesejahterahan bersama adalah 1) Salah satu tugas dan peran penting dari pendamping desa adalah membantu desa membentuk dan memanfaatkan jaringan sosial serta mengembangkan kerjasama, baik kerjasama antar desa maupun dengan pihak ketiga guna mewujudkan tujuan dari pembangunan desa, sebagaimana dinyatakan dalam UU Desa, untuk itu diharapkan pendamping lokal desa dapat menjalin kerjasama dengan berbagai pihak demi terlaksananya pembangunan desa yang lebih baik, 2) Perlunya peran aktif dari pemerintah desa untuk mengikuti setiap arahan dari pendamping lokal desa guna dapat mandiri dalam pembangunan, 3) Diharapkan pendamping lokal desa dapat meningkatkan peran serta masyarakat dalam perencanaan pembangunan, sehingga dapat mewujudkan pembangunan yang partisipatif.

\section{Referensi}

Pemerintah Republik Indonesia. (2014). Pasal 112 Ayat 4 Undang-Undang Nomor 6 Tahun 2014 Tentang Desa.

Pemerintah Republik Indonesia. (2015). Peraturan Menteri Desa Pembangunan Daerah Tertinggal, dan Transmigrasi Nomor 3 Tahun 2015 tentangPendampingan Desa. Pasal 1 ayat 9.

Republik Indonesia. (2014). Pasal 1 Angka 1 Undang-Undang Nomor 6 Tahun 2014 Tentang Desa.

Susanti, M. H. (2017). Peran Pendamping Desa dalam Mendorong Prakarsa dan Partisipasi Masyarakat Menuju Desa Mandiri di Desa Gonoharjo Kecamatan Limbangan Kabupaten Kendal. Integralistik, 28(1), 29-39. 
Suswanto, B., Windiasih, R., SUlaiman, A. I., \& Weningsih, S. (2019). Peran Pendamping Desa Dalam Model Pemberdayaan Masyarakat Berkelanjutan. Jurnal Sosial Soedirman, 2(2), 4060.

Undang-Undang. (2014). Pasal 1 ayat 1 UU No 6 tahun 2014 tentang Desa.

Widjaja, H. (2012). Otonomi Desa. PT. Raja Grafindo Persada.

Pemerintah Republik Indonesia. (2014). Pasal 112 Ayat 4 Undang-Undang Nomor 6 Tahun 2014 Tentang Desa.

Pemerintah Republik Indonesia. (2015). Peraturan Menteri Desa Pembangunan Daerah Tertinggal, dan Transmigrasi Nomor 3 Tahun 2015 tentangPendampingan Desa. Pasal 1 ayat 9.

Republik Indonesia. (2014). Pasal 1 Angka 1 Undang-Undang Nomor 6 Tahun 2014 Tentang Desa.

Susanti, M. H. (2017). Peran Pendamping Desa dalam Mendorong Prakarsa dan Partisipasi Masyarakat Menuju Desa Mandiri di Desa Gonoharjo Kecamatan Limbangan Kabupaten Kendal. Integralistik, 28(1), 29-39.

Suswanto, B., Windiasih, R., SUlaiman, A. I., \& Weningsih, S. (2019). Peran Pendamping Desa Dalam Model Pemberdayaan Masyarakat Berkelanjutan. Jurnal Sosial Soedirman, 2(2), 4060 .

Undang-Undang. (2014). Pasal 1 ayat 1 UU No 6 tahun 2014 tentang Desa.

Widjaja, H. (2012). Otonomi Desa. PT. Raja Grafindo Persada. 